\title{
THE DYNAMICS OF PRICE ADJUSTMENT AND RELATIONSHIP IN THE FORMAL AND INFORMAL BEEF MARKETS IN NAMIBIA
}

\author{
Kennedy Sean Kalundu ${ }^{1}$ and Ferdi Meyar ${ }^{2}$
}

\section{ABSTRACT}

Beef prices have increased significantly in Namibia in recent years. The main drivers of the increases in beef producer prices points to the high input cost and drought leading to excessive culling of breeding herds among commercial farmers. Johansen multivariate test of cointegration and multivariate vector error correction model are used to investigate the price adjustment and the existence of long-run relationship among the beef prices at various stages of the value chain. The results shows that the beef cattle prices are integrated and exhibit a long run relationship. Formal (for grade A) and informal (grade C) beef cattle prices suggest that they adjust to long-run equilibrium at different speed. For instance, prices in the formal markets adjusts to disequilibrium at about $81 \%$, while prices in informal markets adjust to disequilibrium at $63 \%$. Granger causality results indicates the log price of grade $\mathrm{C}$ beef cattle in the informal market does not cause Granger log of beef cattle price of grade A cattle in the formal market, $\log$ of wholesale beef price of grade A beef and $\log$ of export beef price of grade A unidirectional at the $1 \%$ level of significance. The adjustment can be attributed to the objectives and the nature beef markets understudy, coupled to the lack of efficient price information linkages between formal and informal beef cattle markets.

Keywords: price adjustment; multivariate cointegration vector error correction model, Namibia formal and informal beef markets

JEL code: Q22

\section{INTRODUCTION}

The lack of studies in price relationship in the beef sector in Namibia has led to inaccuracies in providing important measurement of the degree to which supply and demand shocks arising in one sector (formal) are transmitted to informal sector, or from the European market and South Africa to the Namibian beef market. Producers, consumers and policy makers are concerned about price relationships in the beef cattle markets in Namibia. It is believed that price relationships play a vital role in Namibia's level of beef cattle transaction and therefore

\footnotetext{
${ }^{1} \mathrm{PhD}$ student and corresponding author. Department of Agricultural Economics, Extension and Rural Development, University of Pretoria, South Africa. skkalundu@gmail.com.

${ }^{2}$ Professor and Director of Bureau for Food and Agricultural Policy (BFAP), University of Pretoria
} 
has welfare implications for cattle producers in both the formal and informal markets of Namibia. In fact Ben-Kaabia et al. (2005) argue that price movements at different points of transaction and along the supply chain may have important implications for producers' and consumers' welfare. Therefore, producer and retail beef price movements, disparities and formation are important to be understood for proper policy formulation. Prices are among the most followed, analysed and sometimes manipulated by role players (Ben-Kaabia et al., (2005). However, controlling prices could be costly and even become pointless, when informal traders and butchers continue to sell cattle and beef in open unregulated markets. It is the understanding of this study that price play a vital role in the domestic trade (Meyer, 2006) and should be studied carefully to provide policy issues that be important tools for developing mechanisms for price discovery in the domestic beef cattle market.

Live cattle and beef price movements in recent year have been a result of changes in both supply and demand. Changes in supply and demand dynamics have pointed to herd rebuilding patterns that takes 8 to 12 years due to the biological nature of cattle production (Von Bach et. al, (1990)), the dynamics of the land tenure system (freehold - with enforced property rights resulting into appropriate rangeland and grazing management systems and non-freehold - based on customary law and leasehold without enforced property rights, limited or restricted rangeland and grazing management systems), the occasional outbreaks of foot and mouth disease (FMD) particularly in the northern communal areas, such as the Zambezi region, input (feed and veterinary) costs and variations in slaughter weights appear to have influenced such changes (Meat Corporation report, 2014).

The study investigates the price relationships and adjustments among the prevailing prices for grade $\mathrm{A}$ beef cattle in the formal and grade $\mathrm{C}$ in the informal markets. The study analyses the price relationships between communal farm beef cattle price for grade $\mathrm{C}$ cattle, commercial beef cattle prices (producer price for grade A), beef (wholesale and export) prices for grade A. The average prices of auction prices are used because they yield the normal profit based on the Agra Professional Service report (2012) in this study. The emphasis is placed on the long-run relationship and dynamics of the speed of price adjustment. The question then is, what form of policies would efficiently regulate price relationship, formation and movement in the formal and informal beef cattle markets, and the kind of measures to adopt in order to improve the competitiveness in terms of pricing. Under the same principle, this article examines the short run and long run effects of the domestic live cattle and beef prices in Namibia. Emphasis is placed on the prices of beef cattle in the informal and formal beef cattle markets. In this article, prices are evaluated using the dynamic price transmission framework of applying of the Johansen multivariate cointegration (JMC) and the Vector Error Correction Model (VECM). Both the JMC and VECM frameworks are advantageous in the sense that they are versatile and provide ease with interpretation of results (Lütkepohl, 2005 and Becketti, 2013). For example the VECM displays desirable parameter estimates of short-and long-term relationship between multiple time series data such price series in this article

Therefore this paper attempts to bridge the knowledge gap that exists on price adjustment and relationship between the formal and informal beef cattle markets in Namibia. Based on classical economic theory, it is also important to investigate the notion that informal beef markets are a derivative of the formal beef market, and being derivative markets, beef cattle prices are expected to behave symmetrically. Therefore, it is important to establish the kind of policies that can be recommended on price adjustment and relationship for a dualistic and dynamic beef cattle markets such as in Namibia 
It is also important to investigate whether the informal beef market in Namibia is a derivative of the formal market. Beef price movements in recent year have demonstrated changes in both supply and demand. It is argued in this article that farmers are faced with excessive production costs problems that leads to export of more than 400,000 weaners to South Africa (Meat Board report, 2013). During the occurrence of drought, farmers are faced with decisions to reduce the herd size of the cattle. These decisions forces prices to take a deep, dues to hikes in supply of slaughter stock. Conversely, after drought, beef cattle producers are faced with herd rebuilding decisions, where supply follows a lowest ebb and surges in prices are recorded due to high demand surpassing supply of slaughter cattle (Meat Corporation report 2013 and 2014).

Table 1 shows that price in the communal sector (characterised by thinly distributed informal cattle traders) increased by $91 \%$ in real terms compared to $65 \%$ in the commercial sector. Price movement from 1990 to 2014 indicates that the price gap between live cattle sold in informal market to that of cattle sold in the formal market is $25.3 \%$ in nominal terms, while in real term the gap is $0.3 \%$ in absolute terms. The variation in prices can be attributed to the quality of cattle originating from the two dualistic sub-sectors, with good quality cattle coming from well managed production systems in the commercial farms and less to poor quality cattle produced from high populated (Figure 2) and often over grazed communal areas (Agra Professional Service report, 2012).

Table 1: Namibian beef cattle price movements $(1990$ - 2014)

\begin{tabular}{|c|c|c|c|c|c|}
\hline \multicolumn{6}{|c|}{ Live cattle and beef price increases in nominal terms } \\
\hline & $\begin{array}{c}\text { Informal price } \\
\text { (Grade C live } \\
\text { cattle) } \\
\end{array}$ & $\begin{array}{c}\text { Formal price } \\
\text { (Grade A Live } \\
\text { cattle) } \\
\end{array}$ & $\begin{array}{l}\text { Producer price } \\
\text { (Grade A beef) }\end{array}$ & $\begin{array}{c}\text { Wholesale } \\
\text { price } \\
\text { (Grade A beef) } \\
\end{array}$ & $\begin{array}{c}\text { Export price } \\
\text { (Grade A beef) } \\
\end{array}$ \\
\hline $\begin{array}{l}\text { Price movement } \\
\text { from } 1990 \text { to } 2014 \text { : }\end{array}$ & $255.10 \%$ & $229.82 \%$ & $377.50 \%$ & $237.16 \%$ & $151.94 \%$ \\
\hline \multicolumn{6}{|c|}{ Live cattle and beef price increases in real terms } \\
\hline $\begin{array}{l}\text { Price movement } \\
\text { from } 1990 \text { to } 2014:\end{array}$ & $164.06 \%$ & $164.36 \%$ & $282.72 \%$ & $170.24 \%$ & $101.94 \%$ \\
\hline Difference & $91.04 \%$ & $65.46 \%$ & $94.78 \%$ & $66.92 \%$ & $50.01 \%$ \\
\hline
\end{tabular}

Source: Author's compilations using data provided by the Ministry of Agriculture, Water and Forestry statistical bulletins of 2005 and 2009 and monthly price data from the Meat Board of Namibia (2014) accessible on the portal (www.nammic.com.na).

It should also be noted that beef export price effects arise from the exchange currency impulsiveness of tradeable beef. Exchange rate impulsiveness is the volatility of domestic currency expressed in terms of the currency of a trading partner/country (Meyer, 2006). It is noted that the scenario where there is currency depreciation, an exporter is expected to have reduced earnings, but makes exportable beef cheaper for importing trading partner. The converse is true as well. Therefore, currency depreciation is usually not a favoured option for trading. In case of the Namibian beef market, where Namibia is a surplus producer and net exporter of weaners, and reliant on South African and European markets. Policy movements in these two trading partners has implications on the retail and producer beef prices in Namibia. In particular, exchange rate volatility of the Euro has implications on profitability for beef exporters. 
Price movements are synonymous to the above or below normal rainfall, where demand for stocking herd increases or decreases to increase or decrease production. Therefore, economic theory suggests that in a supply response framework, the price of cattle and that of derivate product (beef) and rainfall are major determinants of production variation (Von Bach et al., (1990). Meanwhile exogenous factor such as demand from slaughterhouses, abattoirs and butcheries creates competition and wedge between re-stocking and slaughtering. The tug-of war between supply response and demand response determinants eventually dictate the competitive price (Meyer, 2006 and Xing, 2012)

Figure 1 is a graphical representation of real prices of live cattle and beef, where, IBPRICE is informal live beef cattle price (price per kilogram for grade $\mathrm{C}$ cattle), FBPRICE is the formal auction live beef cattle price per kilogram of slaughter weight of grade A cattle; and beef prices depicted by other exogenous variables such as PBPRICE - the producer price (N\$ per kilogram of grade A) of beef, WBPRICE is the wholesale price per kilogram for beef cuts (N\$ per kilogram for grade A beef) and EBPRICE is the beef export price per kilogram of beef cuts of grade A beef. Figure 1 shows the direction of the relationship between the live cattle and beef prices in the long-run. This claim is validated after applying the Johansen cointegration test

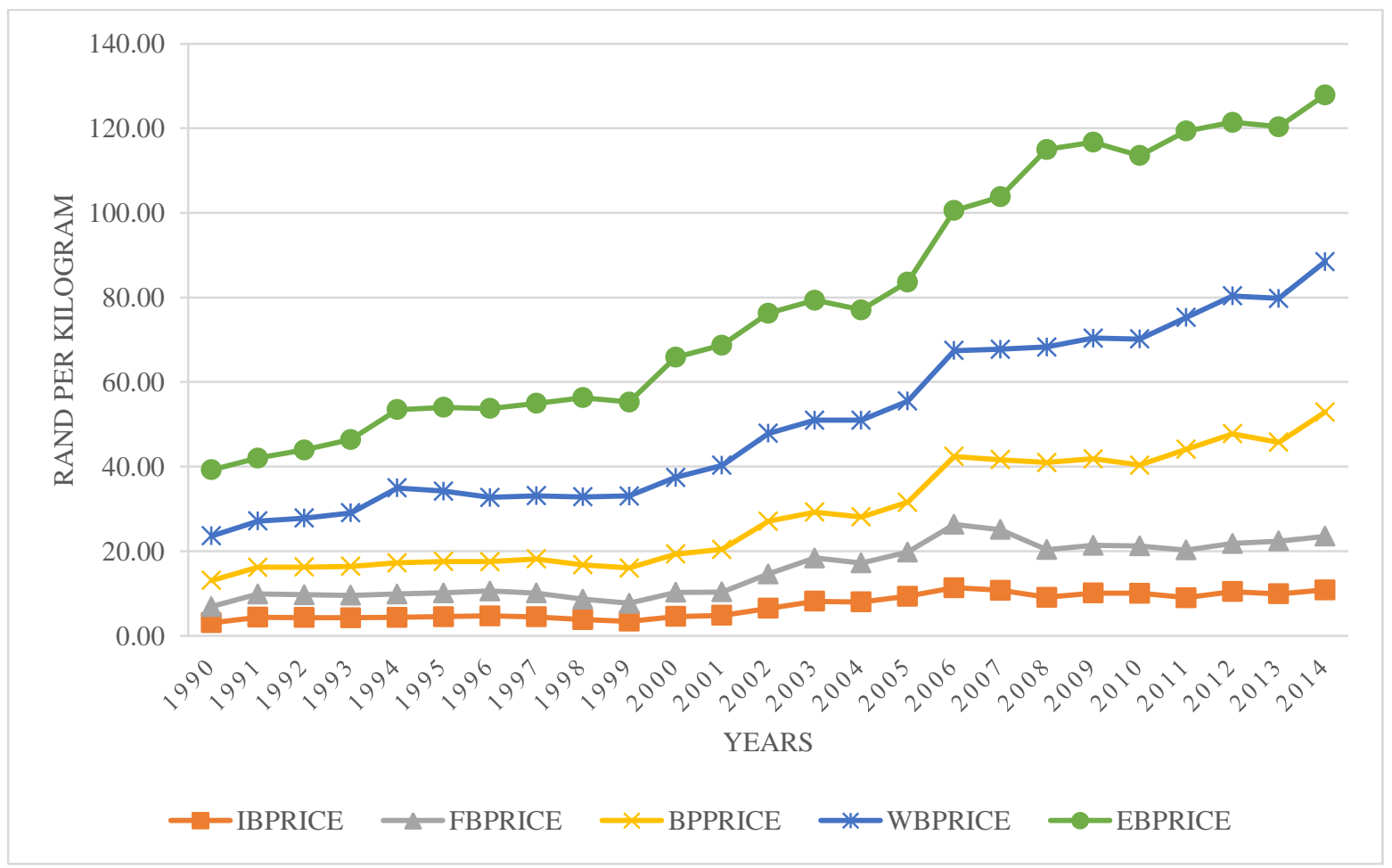

Figure 1: Shows the real live cattle and beef prices in levels (1990 -2014)

By comparison and definition, informal market is composed of small beef cattle traders and small slaughter houses operating in small villages and settlements, but slaughter cattle on daily basis after securing slaughter permits. Informal beef seller do not adhere much to health standards and regulation, often would sell beef carcass in open areas with no refrigeration or cooling system (Agra Professional Service report, 2012). Therefore, they cannot compete well with Meat Corporation of Namibia (locally known as MeatCo) and other formal market channels such as auctions, slaughterhouses and butcheries on hygiene and quality particularly 
for processed beef cuts. MeatCo is registered as parastatal and owned by registered cattle producers and a chief buyer of beef cattle in Namibia and offers superior quality at high price per kilogram (Meat Corporation report, 2013 and 2014), whilst small informal traders offer compromised quality at lower price per kilogram to a different market segment. In fact the Agra Pro Vision report (2012) indicate that the quality of cattle produced and marketed in the informal areas, particularly in NCAs is lean and mature oxen.

Figure 2 show that cattle stocking rates in Namibia depicting the existence of the veterinary cordon fence (VCF) with commercial farmers situated south -VCF and communal farmers practicing their farming activities north - VCF, though a small fraction are also found SouthVCF (MAWF report, 2012). It is also argued that dynamism of the land tenure system in Namibia particularly in the communal area that contributes to the reduced productivity of land due to overstocking of cattle and overgrazing (Agra Professional Services report 2012). The land tenure system affects the supply side of beef cattle production in the value chain and resulting in most of the cattle in the NCA classified as grade $\mathrm{C} 0$ to $\mathrm{C} 1$, therefore, this implies that cattle marketed in NCAs are older than 3 years and lean). In addition the report reveal that about $3.7 \%$ of the land available for grazing is overstocked to point to where it exceed the required carrying capacity for grazing.

The duality in the beef cattle sub-sector have resulted in the situation that formal and informal market have their different demand and supply dimensions, different objectives for consumers and producers and have different rules and institutional attributes. Coupled to this, is the high transaction costs for searching and screening potential buyers, negotiating of contracts, and monitoring and enforcing the adherence to the contract.

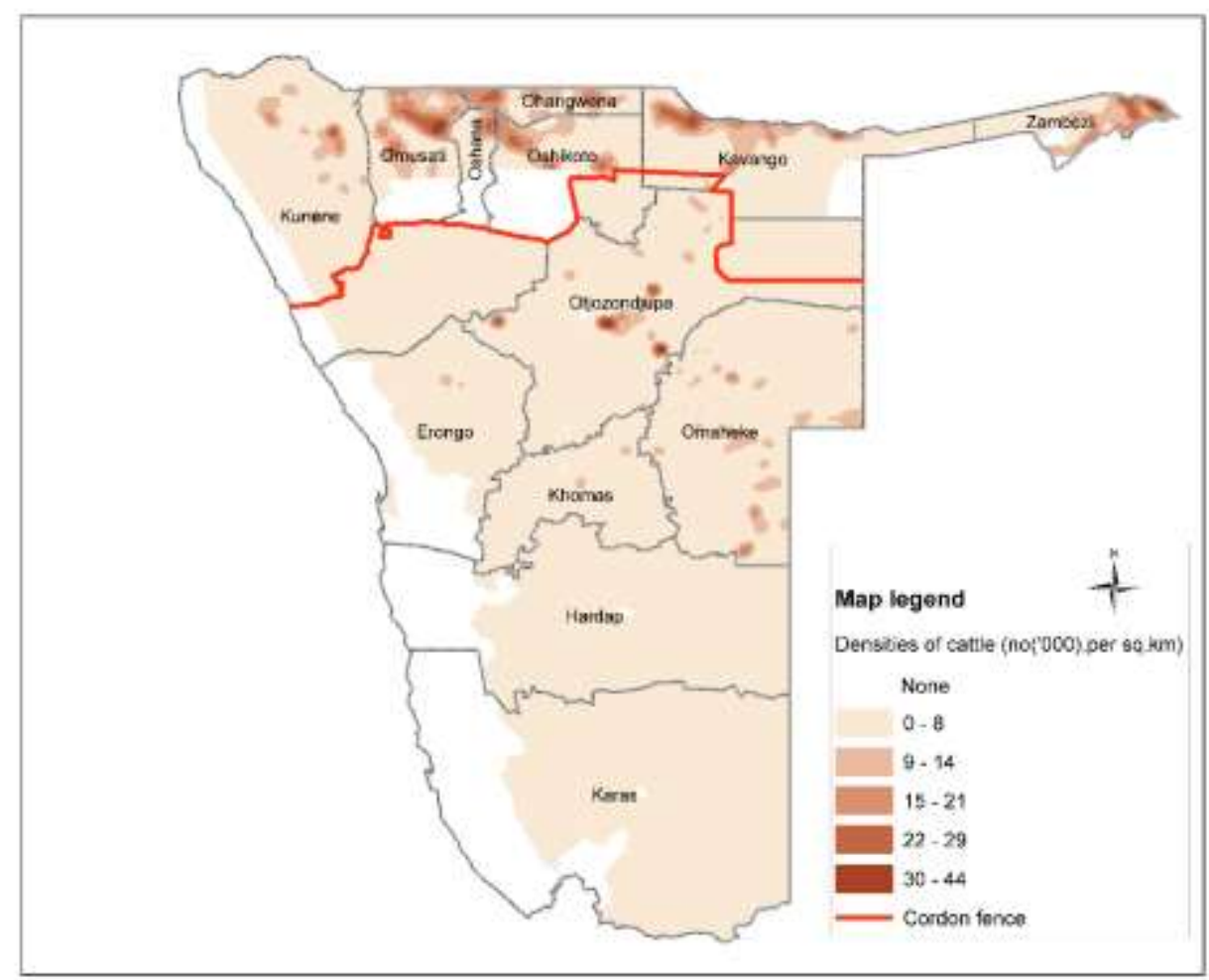

Figure 2: Map of Namibia depicting the cattle densities and distribution in 2013Source: Ministry of Agriculture, Water and Forestry, 2013 
In 2014, the Namibian government through the Ministry of Finance (MoF) gazetted a levy advocate the introduction of a value addition requirement in the domestic market. The requirement states that all market-ready-beef cattle should be slaughtered and processed domestically, and exported as beef cuts. Under the same requirement, if a producer exports a beef cow or ox at live weight of 450 kilogram and more, a 30 percent is levied on the selling price and a form of tax is forwarded to the MoF (2014). A policy seen to encourage more domestic slaughter of market ready cattle and utilization of domestic slaughter facilities. However, this requirement has implications on the supply of beef cattle to local abattoirs, where domestic prices for live cattle are observed to be low compared to prices prevailing in the South African cattle market. Another setback for the beef cattle farmers in Namibia is the cost implications of rearing weaners to the required slaughter weight of 450 kilogram. In addition, government introduced policies and regulations that prohibits animal movement from the North-VCF to the South-VCF, but beef cattle producers South-VCF can sell their cattle stock and move cattle North-VCF. This restriction has caused disparities in the dynamics of supply and demand of slaughter stock and the quality of cattle marketed in northern communal areas.

The article is structured as follows, section 2 discusses the background on price transmission, and this informs the methodology followed in this article, which is elaborated in section 3. Section 4 explains the data in brief and the empirical results and explanation are discussed section 5. Finally, the article provides the policy implications and concludes the article.

\section{BACKGROUND ON PRICE RELATIONSHIP AND ADJUSTMENT}

It is important to emphasize that price is a principal instrument by which various stages of the markets are linked. The nature of price adjustment and speed with which the price shocks are transmitted among beef producers, wholesale and retail channels reflects the actions of market role-players in different market segments (Mkhabela and Nyhodo (2011). Similarly, price transmission can reflect the extent of market integration and the extent of market efficiency (Kelbore, 2013). In recent decades, producers, mostly farmers and legislators are concerned about the efficiency and equity of price formation of beef cattle in Namibia. Producers are of the opinion that the current pricing system pitches producers at the lowest ebb, meanwhile beef processors and wholesaler and retailers are receiving high profit margins. Evaluating the efficiency of the price relationships and adjustments in the Namibian beef market is important because helps to characterize the extent to which the beef cattle market responds to shifts in various domestic beef prices, European market beef prices and South African weaner prices. Understanding beef price relationships and adjustment in the domestic beef sector, their relationship to European prices and South African weaner prices has not been studied and addressed well by role players in the industry. This is the novelty of this study.

In Namibia, market efficiency and price transmission of market information have attracted considerable attention because the beef market sector is seeing more government involvement in creating an allegiance with MeatCo (the main buyer and processor of cattle). Questions about price relationship between the formal market and informal market, and whether beef cattle farmers in the informal market have profited from the prices offered by MeatCo are becoming apparent. It is important to note that about the beef cattle market in Namibia is that, informal beef cattle markets are thin, spatially concentrated and are too small to compete on quality in value chain. Meanwhile, in the formal markets, beef cattle 
processing and retailing is more concentrated, with MeatCo accounting for a larger share in processing and export. Though it can be deduced that, the market structure is more competitive at retail level than at producer level, because there are few processors and many retailers selling beef. Studies of Sahaian et al. (2013); Sarmiento and Allen (2000); and Schroder et al. (2013) infer that concentrated market structure is prevalent to providing incentive for oligopolistic behaviour. Example for this oligopolistic behaviour includes the non-cooperative collusion, strategic price signalling and investment.

There are no studies conducted to evaluate the level of price transmission in the formal and informal beef market. Similarly, there are no studies conducted to determine the price relationship and adjustment in the dualistic, coupled with dynamism in land tenure and production system, like the Namibian beef cattle market. However, there are several studies on price transmission, for example, Saghaian et al. (2013) in a study on the dynamics of price transmission and market power in the formal Turkish beef sector using a vector error correction model show that retail prices tend to rise above equilibrium, whereas wholesale prices tend to fall, therefore, creating an impact on the price margin. The same study show that the speed of adjustment was higher for wholesale than for retail. The adjustment can be attributed to the speed of relay of market information, particularly price information. That study conclude that there exist asymmetric price transmission and a possibility of growing market concentration and inefficiency in the Turkish beef sector.

Other notable studies on pricing involving the threshold VECM includes Conforti (2004); Cutts and Kirsten (2008); El Benni et al. (2014). The bulky of these studies based their analysis on bivariate specification of the VECM model, whilst this study is based on the multivariate VECM framework. Examples of the bivariate VECM model includes the works of Jaleta and Gebermerdhin (2009) study on cointegration of wheat and teff in Ethiopia; Minot (2011) study on transmission of world food price changes to markets in Sub-Sahara Africa and Kelbore (2013) developed a case study to look at world food prices and their transmission to the Ethiopian domestic food prices. Kelbore (2013) used VECM version and principal component approach that included the threshold aspect, but the study did not account for the presence of marketing costs. Several beef studies used cointegration and VECM model specifications to analyse pricing and transmission at different levels in supply chain. For example, Sarmeinto (2000) looks at the dynamics of beef supply in the United States of America (USA) in the presence of cointegration testing of backward-bending hypothesis. Worako et al. (2008); Mkhabela and Nyhodo (2011) and Schroeder et al. (2013) formulated bivariate models to evaluate the demand for beef in South Africa and USA, respectively. Similarly, Cutts and Kirsten (2008) apply the asymmetric price transmission framework on selected commodities in South Africa to investigate the price transmission along the supply chain. However, it is important to distinguish that despite the analysis done in previous studies, both of the mentioned studies were conducted in more developed, organised markets and supply chains.

\section{METHODS}

The section discuss the unit root testing for stationarity, the Johansen multivariate cointegration, VECM and Granger-Causality tests. The Augmented Dickey-Fuller (ADF) and Phillips-Perron (PP) are performed to test for unit (Dickey and Fuller, 1979) among the price series. The Johansen cointegration test (Johansen, 1988 and 1992) is used to determine the rank of the cointegrating matrix in the price series. By definition, cointegration describes a long-run, or equilibrium relationship between the variables (Sims, 2014). This definition 
makes cointegration an ideal analysis technique to ascertain the existence of a long-term relationship between the formal and informal beef cattle price series in Namibia. The dynamic behaviour of the variables can therefore be described by an error correction model. However, to aid the necessity of the error correction model, we proceed by performing the Johansen multivariate cointegration. The Johansen multivariate cointegration is a superior analysis because it requires calculating two test to determine the number of cointegrating vectors using maximum likelihood estimation procedures. The two test used are, the Maximum eigenvalue $(\boldsymbol{\lambda}$-Max) and the Trace $(\boldsymbol{\lambda}$-Trace) statistic tests. The tests are important procedure to determine the number of cointegrating relations among variables (Enders, 1995). The Maximum eigenvalue test statistic evaluate the null hypothesis of $r$ cointegrating relations against the alternative of $r+1$ cointegrating relations for $r=0,1,2 \ldots n-1$. Where $r$ is the rank of the matrix of cointegrating relationships (source). The test statistic is calculated as:

$$
L R_{\max }(r /(n+1))=-T * \log (1-\hat{\lambda})
$$

Where $\lambda$ is the Maximum eigenvalue and $T$ is the sample size. While the Trace statistic tests the null hypothesis of $r$ cointegrating relations against the alternative of $n$ cointegrating relations. In this case $n$ is the number of variables in the equation for $r=1,2 \ldots n-1$. Trace statistic equation take the following form;

$$
L R_{t r}(r / n)=-T * \sum_{i=r+1}^{K} \log (1-\hat{\lambda})
$$

In most cases, Trace and Maximum eigenvalue statistics yield similar results. In scenarios where the results of the test are different, the Trace statistic test is more superior and preferred. In addition, Johansen tests according to equation (1) and (2) could test both the unrestricted model (with a trend) and restricted model (without a trend). Thus, the test for cointegrating relationship between the Namibian beef cattle price series, where $n=2$, becomes the test for the null hypothesis: $r=0$ and $r=1$ with and without a trend, starting without trend.

The model identified in this article is a four variable models, hence a multivariate model, which hypothesize that informal beef cattle price series is a function of beef cattle prices in the formal market; augmented by the beef price (wholesale and beef export).

$$
I B P R I C E_{t}=f\left(F B P R I C E_{t}, W B P R I C E_{t}, E B P R I C E_{t}\right)
$$

Where, the variable are defined as given in section preceding Table 1 and before Figure 1 The $t$ denotes the time trend and takes individual year (from 1990 - 2014). Conforti (2004) suggests that in order to reduce data variability, econometrics analysis should be carried out on the logarithms of the prices. This study has followed the Conforti (2004) advice and converted all the price series into logarithms. The additional advantage of logarithm transformation of time series processing is that, coefficients can be easily interpreted as elasticities.

As stated previously, the VECM is applied after detecting that there exist a long-run relationship between the variables. The important nature of the VECM is to detect the shortrun properties of the cointegrated series (Lütkepohl, 2005). Usually, if there are no cointegrating parameters, the VECM is not required. Therefore, it is advisable to just estimate the Granger-Causality to determine the causal relationships between variables (Engle and Granger, 1987). By illustration, the VECM framework departs from the Vector Autoregression (VAR) with $p$ lags: 


$$
\text { Price }_{t}=v+A_{1} \text { Price }_{t-1}+A_{2} \text { Price }_{t-2}+\cdots+A_{p} \text { Price }_{t-p}+\epsilon_{t}
$$

Where Price $_{t}$ is $\mathrm{K} \times 1$ vector of variables (price series), $v$ is a $\mathrm{K} \times 1$ vector of parameters (intercept terms), $A_{1}-A_{p}$ are $\mathrm{K} \times \mathrm{K}$ matrices of parameters, and $\epsilon_{t}$ is a $\mathrm{K} \times 1$ vector of disturbance terms. Hence, $\epsilon_{t}$ has a zero mean and covariance matrix $\sum$, and is independently, identically distributed (i.i.d) normal over time. It is important to note that $\operatorname{VAR}(p)$ presented above can be rewritten as a $\operatorname{VECM}$. The expression $\operatorname{VAR}(p)$ to $\operatorname{VECM}$ follows after performing some technical manipulation of the algebra of equation 4 :

$$
\Delta \text { Price }_{t}=v+\text { Mrice }_{t-1}+\sum_{i-1}^{p-1} \Gamma_{i} \Delta \text { Price }_{t-1}+\epsilon_{t}
$$

Where $\Delta$ Price $_{t}$ is a $\mathrm{K} \times 1$ matrix of price series, representing Price $_{t}-$ Price $_{t-1}$; and $v$ is a $\mathrm{K} \times$ 1 vector of intercept terms; $\Pi=\sum_{j=1}^{j=p} A_{j}-I_{k}$ a matrix that captures the long-run relationships among the price series. If we assume that $\Pi$ has reduced rank that varies $0<r<$ $\mathrm{K}$ so that it can be expressed as $\Pi=\alpha \beta^{\prime}$, where $\alpha$ and $\beta$ are both $r \times K$ matrices of rank $r$. Then $\alpha$ matrix describes the speeds of the adjustment, where each price series returns to longrun equilibrium and the $\beta$ matrix captures the cointegrating vectors in a long-run relationship (Lütkepohl, 2005 and Becketti, 2013).

The $\Gamma_{i} \Delta$ Price $_{t-1}$ terms captures the short-run relationships among the elements of Price $_{t}$ matrix. While, the $v$ and $\epsilon_{t}$ in equation 4 and 5 are similar. For example, with 5 variables and two cointegration vectors and ignoring $v$ and setting $\Pi=\alpha \beta$.

\section{DATA AND DESCRIPTION OF VARIABLES}

The study used beef cattle price time data from the Meat Board of Namibia and Ministry of Agriculture, Water and Forestry. The data consists of annual average price series of beef cattle in the informal market denoted by the informal beef cattle price series (open market price per kilogram / price per head of cattle for slaughter weight of $\mathrm{C}$ graded cattle) and formal market; formal auction beef cattle price per kilogram of slaughter weight for A graded cattle; control variables: wholesale price per kilogram for beef cuts of A graded beef; and the beef export price per kilogram of beef cuts of A grade beef. The study uses 24 observations from 1990 to 2014. Price data from the informal beef cattle trade are obtained from the Ministry of Agriculture statistical bulletins for 2005 and 2009, and Meat Board Master Plan study done by Agra Professional Service division in 2012. The consumer price index was obtained from the National Statistical Agency ((NSA) (2013)). All prices were deflated using the consumer price index, base year 2012 in order to account for price fluctuations over the years and obtain the real prices. Therefore, in this study price means real beef cattle prices for grade $\mathrm{C}$ cattle in the informal market and grade A cattle in the formal market. Prices are expressed in South African rand per kilogram $(\mathrm{R} / \mathrm{Kg})$. The South African rand and Namibian dollar are pegged one-to-one, meaning, one South African rand is equivalent to 1 Namibian dollar and vice versa.

Price data analysis showed steady erratic movements trending with a potential for integration of order one - I(1) processes (Figure 1). In a competitive market, current and past price series contain all the information available, meaning that next year's price will be a random walk from this year's price. Evidently, the price series representing the wholesale price has been trending high over the years, while the export beef price series trended high and from 2008 the price trended downwards. This widening in the price series is not indicative of buying 
power, because supply shocks such as production costs and severe droughts may be the cause for this phenomenon.

Appendix table indicates that on the average the informal beef cattle prices are lower than that of the prices offered in other markets and about 3 times lower than the wholesale beef price and about 4 times lower than the export price. On the contrary, informal beef cattle price is relatively comparable to the average beef cattle auction price in the formal markets. This can be attributed to the fact that live cattle are priced at live weight basis in all markets. Cattle traded in the informal market are mainly small framed cattle with an average live mass of 198 kilogramme compared to 280 - 325 kilograms in the formal markets (Agra Professional Service report, 2012 and Meat Board report, 2013).

\section{RESULTS AND DISCUSSION}

\subsection{Unit root test}

The section begin with a descriptive analysis of the characteristics of individual price series displayed in Figure 1. In other words, the study examine the stationarity properties of the univariate time series variables. The beef cattle price series are integrated of order one - I(1), deemed to have unit root. The results of the unit root tests in levels are reported in Table2. It is clear from Table 2 that the null hypothesis of no unit for all the price series is rejected at their first difference because the ADF and Phillip-Perron (PP) test statistics are greater than the critical value at $1 \%$ and $5 \%$ levels of significance, respectively. Both the ADF and PP tests indicates that the first differenced data of beef cattle price series in Namibia is stationary in their first levels. Therefore, having the same order of integration is one requirement for cointegration, but does not necessarily mean there is cointegration relationships. Using the Johansen approach of Lagrange Multiplier (LM) and Trace statistics is appropriate in this study.These results therefore necessitate the need to perform the multivariate cointegration procedure.

Table 2: Augmented Dickey-Fuller and Phillips-Perron Tests for Unit root on log of price series

\begin{tabular}{|c|c|c|c|c|}
\hline & \multicolumn{2}{|c|}{ Augmented Dickey-Fuller Test (ADF) } & \multicolumn{2}{|c|}{ Phillips-Perron test statistic (PP) } \\
\hline \multicolumn{5}{|c|}{ Data in levels } \\
\hline Variables & $\begin{array}{c}\text { Constant without a } \\
\text { trend }\end{array}$ & Constant with trend & $\begin{array}{c}\text { Constant without a } \\
\text { trend }\end{array}$ & $\begin{array}{l}\text { Constant with } \\
\text { trend }\end{array}$ \\
\hline L_IBPRICE & -1.2643 & -1.8379 & -1.2643 & -1.9668 \\
\hline L_FBPRICE & -1.3935 & -2.0083 & -1.4139 & -2.0083 \\
\hline L_WBPRICE & -0.8389 & -1.4136 & -1.1990 & -2.7086 \\
\hline L_EBPRICE & -1.2066 & -3.8564 & -1.2067 & -1.9674 \\
\hline \multicolumn{5}{|c|}{ Data in first difference } \\
\hline L_IBPRICE & $-4.9678 * *$ & $-4.7761 * *$ & $-4.9678 * *$ & $-4.7761 * *$ \\
\hline L_FBPRICE & $-4.8969 * *$ & $-4.7255 * *$ & $-4.8789 * *$ & $-4.7393 * *$ \\
\hline L_WBPRICE & $-4.4697 * *$ & $-4.8517 * *$ & $-5.0914 * *$ & $-5.2299 * *$ \\
\hline L_EBPRICE & $-3.3132 * *$ & $-3.3969 * *$ & $-4.5794 * *$ & $-4.7500 * *$ \\
\hline
\end{tabular}

Note:* denotes that the null hypothesis of stationarity is rejected at $1 \%$ level of significance and $* *$ is rejection at $5 \%$ level of significance based on Akaike Info Criterion (AIC) and Phillips-Perron (PP) test, respectively. 


\subsection{Determination of the rank and cointegrating results}

The determination of lag length is trade-off between the curse of dimeeynsionality and reduced models, which are not appropriate to indicate the dynamic adjustment (Sims, 2014). The information criteria function are used to determine the lag length in this study. The information criteria seeks to handle the trade-off between a parsimonious model and a comprehensive model. We have included one lag so that we can check the correlogram for autocorrelation. Autocorrelation is tested with 5\% confidence interval. The goal is to eliminate the presence of autocorrelation. Sufficiently enough, no autocorrelation values were observed at our confidence intervals, and we have dealt with the problem of autocorrelation. We choose to agree with Schwarz (SC) and Hanna-Quinn (HQ) Information Criterion that chose 1 lag instead of the Akaike Information Criterion (AIC) and Final Prediction Error (FPE) who indicated a lag length of 3 . We chose 1 lag length to avoid the loss of more observations and not change the information criteria.

The cointegrating matrix is estimated using the Johansen methodology, based on equations (1) Trace statistics and (2) Maximum eigenvalue statistics to determine the rank of the cointegrating matrix. Table 3 summarizes the cointegrating results. The testing procedures start with testing for zero cointegrating relationship as indicated in the maximum rank column - a maximum rank of zero. The null hypothesis is that the number of cointegrating relationship is equal to $r$ (given by the maximum rank column of the output). The alternative hypothesis is that there are more than $r$ cointegrating relationships among the beef cattle price series.

It is noted from Table 3 that both trace and maximum eigenvalue test statistics that the null hypothesis $\left(H_{0}: r=0\right)$ is rejected up to the $H_{0}: r=1$, because the trace and maximum test statistics are greater than the $5 \%$ critical at the level of significance $(118.73>69.82$, when $r=$ 0 , and $56.21>47.86$ when $r=1)$. This implies that we reject the null hypothesis of no cointegration at $r=0$ and $r=1$ and accept there is 2 (where $H_{0}: r=2(28.90<29.78$ at $5 \%$ level of significance) cointegration relationship among the beef price series in Namibia.

Table 3: Johansen multivariate cointegration results

\begin{tabular}{|c|c|c|c|c|}
\hline $\begin{array}{c}\text { Hypothesized } \\
\text { number of } \\
\text { cointegrating } \\
\text { equations }\end{array}$ & $\lambda$-Trace statistic & $\begin{array}{c}\text { Critical value } \\
\mathbf{( 5 \% )}\end{array}$ & $\begin{array}{c}\lambda \text {-Max -Eigen } \\
\text { statistic }\end{array}$ & $\begin{array}{c}\text { Critical value } \\
\mathbf{5 \%})\end{array}$ \\
\hline $\boldsymbol{r}=0$ & 118.73 & 69.82 & 62.52 & 33.87 \\
\hline $\boldsymbol{r} \leq 1$ & 56.21 & 47.86 & 28.30 & 27.58 \\
\hline $\boldsymbol{r} \leq 2$ & $28.90^{* *}$ & 29.78 & $19.47 * *$ & 21.13 \\
\hline $\boldsymbol{r} \leq 3$ & 9.43 & 15.49 & 9.40 & 14.26 \\
\hline $\boldsymbol{r} \leq 4$ & 0.03 & 3.84 & 0.03 & 3.84 \\
\hline
\end{tabular}

Note: ** both the Trace and Max eigenvalues indicates that there are 2 cointegrating long-run relationships between the beef cattle price series. This implies that we reject the null hypothesis of no cointegration at $r=0$ and $r=1$, and accept that there is 2 (where $H_{0}: r=2(28.90<29.78$ for Trace, and $19.47<21.13$ for Max at $5 \%$ level of significance, respectively) cointegration relationship among the beef cattle price series in Namibia.

\subsection{Vector error correction model result}

Overall, the VECM output in indicates that the model fits well, as supported by the stability of model process. The coefficient on informal beef cattle price in the cointegrating equation is statistically significant. Table 4 indicate that parameters in this multivariate model have the 
correct sign and imply mild to rapid adjustment toward equilibrium (Lütkepohl, 2005). When the predictions from the cointegrating equations are positive, informal beef cattle price is above its equilibrium value and drifts away from the equilibrium. Thus, implies that when the average beef cattle price in the informal market is high, it quickly falls back toward the formal auction beef cattle price per kilogram. The estimated coefficient for formal beef cattle price implies that the price is high compared to the equilibrium price series, the average formal beef cattle price should quickly adjust towards the informal average beef cattle price. VECM result illustrates that, for the informal beef cattle price to be in long-run equilibrium, it will have to adjust by $63 \%$ of the deviation corrected in each subsequent time period (based on the error-correction terms (ECT) in Table 4). Stated, differently, about $63 \%$ of disequilibrium is corrected each year by changes in log of informal beef cattle price. Similarly, for formal beef cattle price should adjust by minus $81 \%$ based on the ECT.

Having determined that there is cointegrating equation between the informal and formal beef cattle price, it should be noted that the other price series (WBPRICE) were found to be insignificant at the 5\% level in the first and second cointegrating equation. VECM facilitates a straight forward economic interpretation, such as the existence of long-run equilibrium and how the price series adjusts to the identified equilibrium. These equations can be specified as follows:

The first cointegrating long-run equation is given:

$$
L \_I B P R I C E_{t-1}=-0.2655+0.4588 L \_W B P R I C E_{t-1}-0.2078 L \_E B P R I C E_{t-1}
$$

And the second long-run cointegrating equation is given as:

$$
L_{-} F B P R I C E_{t-1}=-0.2319+0.4443 L_{-} W B P R I C E_{t-1}-0.2003 L_{-} E B P R I C E_{t-1}
$$

We interpret the estimates based on Lütkepohl (2005); Baltagi (2008) and Becketti (2013). The parameters in the first and second equation as indicating an equilibrium relationship between the average beef cattle price series for the formal auction beef cattle price and the average price series for producer and export prices, respectively. Equation 6 illustrates that informal beef cattle price to be in long-run equilibrium, it will have to adjust by $63 \%$ based on the ECT for equation 6 (Table 4). By doing so, Table 4 and equation 6 illustrates that informal beef cattle market price to be in long-run equilibrium, it will have to adjust by $63 \%$ based on the ECT for equation 6 . This can be stated differently, by saying that about $63 \%$ of disequilibrium is corrected each year (based on the fact that annual data is used in this article) by changes in log of informal beef cattle price. Whilst equation 7 and Table 4 depicts that formal beef cattle price should adjust by minus $81 \%$ based on the ECT. In equation 6 , formal beef cattle price series was omitted because it was found to be insignificant but significant in equation 7. These results are consistent with the finding in Lütkepohl (2005); Baltagi (2008) and Becketti (2013) of the parameters in the first and second equation on finding an equilibrium relationship between the price series and the coefficients are less than a unit. The coefficients in equations 6 and 7 are price elasticities in a long-run equilibrium. 
Table 4: The results of Granger-Causality result based on VECM

\begin{tabular}{|c|c|c|c|c|c|c|c|}
\hline \multicolumn{8}{|c|}{ Independent variables } \\
\hline \multirow{2}{*}{$\begin{array}{c}\text { Dependent } \\
\text { variables }\end{array}$} & \multicolumn{5}{|c|}{$\chi^{2}$-statistics of lagged $1^{\text {st }}$ differenced term } & \multirow{2}{*}{$\begin{array}{l}\mathrm{ECT}_{t-l} \\
\text { coefficient } \\
(t \text {-ratios) }\end{array}$} & \multirow{2}{*}{$\begin{array}{c}\begin{array}{l}\mathrm{ECT}_{t-1} \\
\text { coefficient } \\
(t \text {-ratios })\end{array} \\
\text { Eq.7 }\end{array}$} \\
\hline & $\Delta \mathrm{L} \_$IBPRICE & $\triangle \mathrm{L} \_$FBPRICE & $\triangle \mathrm{L} \_$PBPRICE & $\triangle \mathrm{L} \_\mathrm{WBPRICE}$ & $\Delta \mathrm{L} \_$EBPRICE & & \\
\hline$\Delta \mathrm{LL}_{-} \mathrm{IBPRICE}$ & -- & $\begin{array}{c}0.8304 \\
{[0.3621]}\end{array}$ & $\begin{array}{c}1.2505 \\
{[0.2635]}\end{array}$ & $\begin{array}{c}0.1779 \\
{[0.6732]}\end{array}$ & $\begin{array}{c}0.0268 \\
{[0.8699]}\end{array}$ & $\begin{array}{c}-0.6394 \\
(0.6982)\end{array}$ & $\begin{array}{c}-0.8105 \\
(-0.8748)\end{array}$ \\
\hline$\triangle \mathrm{L} \_$FBPRICE & $\begin{array}{c}1.0905 \\
{[0.2964]}\end{array}$ & -- & $\begin{array}{c}2.3606 \\
{[0.1244]}\end{array}$ & $\begin{array}{c}0.1210 \\
{[0.7279]} \\
\end{array}$ & $\begin{array}{c}0.0796 \\
{[0.7778]}\end{array}$ & $\begin{array}{l}-1.6969^{*} \\
(2.0429)\end{array}$ & $\begin{array}{l}-1.9189^{*} \\
(-2.2839)\end{array}$ \\
\hline$\triangle \mathrm{L} \_$WBPRICE & $\begin{array}{c}0.0181 \\
{[0.8931]}\end{array}$ & $\begin{array}{c}0.0305 \\
{[0.8613]}\end{array}$ & $\begin{array}{c}0.0047 \\
{[0.9451]}\end{array}$ & -- & $\begin{array}{c}0.0086 \\
{[0.9261]}\end{array}$ & $\begin{array}{l}-0.3730 \\
(0.6820) \\
\end{array}$ & $\begin{array}{c}-0.2761 \\
(-0.4990) \\
\end{array}$ \\
\hline$\Delta$ L_EBPRICE & $\begin{array}{c}0.4371 \\
{[0.5085]} \\
\end{array}$ & $\begin{array}{c}0.7107 \\
{[0.3992]} \\
\end{array}$ & $\begin{array}{c}0.1565 \\
{[0.6924]} \\
\end{array}$ & $\begin{array}{c}0.0136 \\
{[0.9071]} \\
\end{array}$ & -- & $\begin{array}{c}-1.0583 \\
(-1.5351) \\
\end{array}$ & $\begin{array}{l}-1.0321 \\
(1.4801) \\
\end{array}$ \\
\hline
\end{tabular}

Note: *denotes significant at 5\% level. The figure in parenthesis (...) denote $t$-statistics and the figure in square brackets $[\ldots]$ represent $p$-value.

\subsection{Granger-Causality test}

It is important to note that cointegration between variables does not specify the direction of a causal relation, if any, between the variables (Sims, 2014). The Chi-square statistic and probability measures causality between the variables. Chi-square statistic and probability values are constructed under the null hypothesis of no causality. The results of pair wise analysis in Table 4, where significant probability values signify the rejection of the null hypothesis. This study reject the null hypothesis if the probability value is more than $1 \%$, conversely, therefore, this study does not reject the null hypothesis if the probability value is less than $1 \%$. Therefore, the results indicates the $\log$ price of grade $\mathrm{C}$ beef cattle in the informal market does not Granger-cause log of beef cattle price of grade A cattle in the formal market, log of wholesale beef price of grade A beef and $\log$ of export beef price of grade A unidirectional at the $1 \%$ level of significance. Similarly, this applies to the log of grade A beef cattle price in the formal market to other price series. The unidirectional causality implies that past values of price series have a predictive ability in the determining the present values of $\log$ price of grade $\mathrm{C}$ beef cattle in the informal market and log of grade A beef cattle price in the formal market.

\section{CONCLUSION AND POLICY IMPLICATION}

The article analysed the short and long term relationships among different price series. VECM model specification was developed within the framework of vector error correction. The study proceeds by testing for the presence of stationarity using the ADF and PP tests. The conclusion from the ADF and PP tests is that the beef cattle price series are integrated of same order, i.e., I(1). The Johansen multivariate cointegration reveal that there are two cointegration equations, these are, for the formal beef cattle price and the informal beef cattle price. VECM results show that price relations can alter the conclusion drawn from price relationship models. The empirical results show that informal market beef cattle prices do not adjust rapidly to equilibrium compared to the beef cattle prices in formal beef market. Informal market beef prices takes about $63 \%$ to adjust to disequilibrium while the formal beef cattle prices adjusts about $81 \%$ to disequilibrium.. The lack of rapid adjustment to equilibrium can be attributed to the fact that the informal beef market is a weaker derivative of the formal market and another attribute is the differences in the objectives of the two markets. This finding is consistency to the findings of Hahn (2010) and El Benni et al. (2014) 
who indicated in their study that looked at transmission of beef and veal prices in different marketing channels that prices in downstream sectors do hardly depend on producer prices.

This study is the first to unpack the price relationships and the price dynamism that exists in the beef cattle market of Namibia. Policy makers should use the results to devise policies that will enable price information to path through to informal market and seek institutions can providing an enabling environment for the informal beef cattle market in order to improve earnings from cattle farming. More importantly, policy aimed at improving productivity of rangelands, the Namibian government should aggressively tackle the allotment of the individual land tenure system, and merge the land tenure system in the dualistic beef cattle sector with training and mentorship on rangeland management can improve the quality of grazing in informal areas both in commercial and communal areas (Agra Professional Service report, 2012), in turn this can improve the quality of cattle coming from all the sub-sectors from grade $\mathrm{C}$ to $\mathrm{AB}$ or $\mathrm{A}$ grade (Meat Corporation report, 2013). The improvement in grades will ensure that cattle producers receive better prices for their live cattle and ultimately their income levels and welfare can improve in a long run. If the speed of adjustment is to improve, then farmers in communal areas should improve their breeding stock and animal husbandry to ensure that their cattle revenues can be relatively move at par with farmers in the commercial sectors and improve their welfare.

\section{REFERENCES}

Agra Professional Vision. 2012. Master plan for increased off take and marketing of cattle and beef from the northern communal areas of Namibia. A study conducted by the Agra Pro Vision service division of Agra Cooperative for the Meat Board of Namibia, Windhoek, Namibia.

Baltagi, H. B. 2008. Econometrics. 4th edition. Berlin Heidelberg: Springer-Verlag.

Becketti, S. 2013. Introduction to time series using Stata. College Station, Texas. Stata Press.

Ben-Kaabia, M., Gil, J. M. \& Ameur, M. 2005. Vertical integration and non-linear price adjustment: The Spanish poultry sector, 21(2): 253-271.

Conforti, P. 2004. Price transmission in selected agricultural markets. FAO Commodity and Trade Policy Research Working Paper No.7, Rome, Italy.

Cutts, M., \& Kirsten, J. F. 2006. Asymmetric price transmission and market concentration: An investigation into four South African agro-food industries. South African Journal of Economics 74(2): 323-333.

Dickey, D. A., \& Fuller, W. A. 1979. Distribution of the estimator for autoregressive time series with a unit root. Journal of American Statistics Association, 74, 427-431.

El Benni, N., Finger, R., \& Hediger, W. 2014. Transmission of beef and veal prices in different marketing channels. Paper prepared for presentation at the EAAE 2014 Congress, August 26 - 29, 2014. Ljubljana, Slovenia.

Enders, W. 1995. Applied econometric times series. John Wiley \& Sons, New Jersey.

Engle, R. F., \& Granger, C. W. J. 1987. Co-integration and error correction: Representation, estimation, and testing. Econometrica 55: 251-276.

Hahn, F. W. 2010. Dynamic and asymmetric adjustment in beef and pork prices. Selected paper prepared for presentation at the Agricultural and Applied Economic Association meeting. Denver, USA, July 25-27, 2010.

Jaleta, M. \& Gebermedhin, B. 2009. Price Cointegration Analyses of Food Crop Markets: The case of Wheat and Teff Commodities in Northern Ethiopia. The International Association of Agricultural Economists Conference Beijing, China; August 16-22, 2009. 
Johansen, S. 1988. Statistical analysis of co-integration vectors. Journal of Economic Dynamics and Control, 12 (2-3): 231-254.

Johansen, S. 1992. Determination of co-integration rank in the presence of a linear trend. Oxford Bulletin of Economics and Statistics, 54: 383-397.

Kelbore, Z.G. 2013. Transmission of World Food Prices to Domestic Market: The Ethiopian Case. University of Trento.

Lütkepohl, H. 2005. New Introduction to multiple time series analysis. New York: Springer

Meat Board of Namibia Report. 2012. Market diversification opportunities for Namibian red meat and meat products outside the European Union, Norway and South Africa. Windhoek, Namibia.

Meat Board of Namibia Report. 2013. Meat production and marketing. The meat industry in Namibia. Windhoek, Namibia.

Meat Board of Namibia data portal. 2014. Accessible at: www.nammic.com.na [accessed on October 15, 2014.

Meat Corporation of Namibia (MeatCo). 2013. Meat Corporation annual report. Windhoek, Namibia.

Meat Corporation of Namibia (MeatCo). 2014. Meat Corporation annual report. Windhoek, Namibia.

Meyer, F.H. 2006. Model closure and price formation under switching grain market regimes in South Africa. Unpublished PhD dissertation, University of Pretoria, Pretoria, South Africa.

Ministry of Agriculture, Water and Forestry (MAWF). 1995. National agricultural policy. Windhoek, Namibia.

Ministry of Agriculture, Water and Forestry (MAWF). Directorate of Planning. 2005. Statistical bulletin. Windhoek, Namibia.

Ministry of Agriculture, Water and Forestry (MAWF). Directorate of Planning. 2009. Statistical bulletin. Windhoek, Namibia.

Ministry of Agriculture, Water and Forestry (MAWF). 2012. Agricultural annual report. Windhoek, Namibia.

Ministry of Agriculture, Water and Forestry (MAWF). 2013. Agricultural annual report. Windhoek, Namibia.

Ministry of Finance (MoF). 2014. Government gazette: an amendment of part 6 of schedule 1: Reinstatement of 30\% levy on all export of live mature cattle: Customs and Excise Act, 1998 (Act No. 20 of 1998) 15 October 1998. Windhoek, Namibia.

Minot, N. 2011.Transmission of World Food Price Changes to Markets in Sub-Saharan Africa. International Food Policy Research Institute (IFPRI).

Mkhabela, T. \& Nyhodo, B. 2011. Farm and retail prices in South African poultry Industry: Do the Twain meet? International food and agribusiness management review. 14 (3): 128-142.

Namibia Statistical Agency (NSA). 2013. Consumer price indexes. Windhoek, Namibia

Saghaian, S., Özertan, G., \& Tekgüç, H. 2013. Dynamics of price transmission and market power in the Turkish beef sector. University of Kentucky, Kentucky, USA.

Sarmiento, C. \& Allen, P. G. 2000. Dynamics of beef supply in the presence of cointegration: A new test of backward-bending hypothesis. Review of Agricultural Economics, 22(2): 421-437.

Schroeder, T., Tonsor. G., \& Mintert, J. 2013. Beef demand: recent determinants and future drivers. A report prepared for the cattlemen's Beef Board, Kansas, USA.

Sims, E. 2. (2014). Notes on time series. USA: University of Notre Dame. USA.

Von Bach Sartorius, H. J \& Van Zyl, J. 1990. Supply of live cattle and beef in Namibia. Agrekon, 29(4): 347-351. 
Worako, T.K., van Schalkwyk, H.D., Alemu, Z.G. \& Ayele, G. 2008. Producer price and price transmission in a deregulated Ethiopian coffee market". Agrekon, Vol 47, no. No 4, pp. 492-508.

Xing, L 2012. Empirical research on spatial and time series properties of agricultural commodity prices. Hanken School of Economics, No. 249: Department of Finance and Statistics, Helsinki, Finland. 


\section{APPENDIX}

Table 5: Raw price data series $(1990-2014)$ in nominal terms.

\begin{tabular}{|c|c|c|c|c|c|}
\hline \multirow[b]{2}{*}{ YEAR } & \multicolumn{2}{|c|}{ Live cattle prices $^{\text {a }}$} & \multicolumn{3}{|c|}{ Beef prices $^{\mathbf{b}}$} \\
\hline & $\begin{array}{c}\text { Informal } \\
\text { Beef Price } \\
\text { (IBPRICE) } \\
\end{array}$ & $\begin{array}{c}\text { Formal Beef } \\
\text { Price } \\
\text { (FBPRICE) }\end{array}$ & $\begin{array}{c}\text { Producer Beef } \\
\text { Price } \\
\text { (PBPRICE) } \\
\end{array}$ & $\begin{array}{c}\text { Wholesale Beef } \\
\text { Price } \\
\text { (WBPRICE) }\end{array}$ & $\begin{array}{c}\text { Export Beef } \\
\text { Price } \\
\text { (EBPRICE) }\end{array}$ \\
\hline & Rand/kg & Rand/kg & Rand/kg & Rand/kg & Rand/kg \\
\hline 1990 & 3.05 & 3.84 & 6.16 & 10.55 & 15.65 \\
\hline 1991 & 4.37 & 5.50 & 6.30 & 10.95 & 14.87 \\
\hline 1992 & 4.28 & 5.39 & 6.54 & 11.60 & 16.11 \\
\hline 1993 & 4.24 & 5.34 & 6.83 & 12.64 & 17.34 \\
\hline 1994 & 4.36 & 5.49 & 7.38 & 17.70 & 18.56 \\
\hline 1995 & 4.49 & 5.66 & 7.41 & 16.65 & 19.79 \\
\hline 1996 & 4.67 & 5.88 & 6.98 & 15.18 & 21.02 \\
\hline 1997 & 4.46 & 5.61 & 8.11 & 14.94 & 21.85 \\
\hline 1998 & 3.83 & 4.82 & 8.11 & 16.05 & 23.48 \\
\hline 1999 & 3.40 & 3.85 & 8.46 & 17.03 & 22.25 \\
\hline 2000 & 4.54 & 4.43 & 9.18 & 18.18 & 28.39 \\
\hline 2001 & 4.81 & 5.21 & 10.17 & 19.90 & 28.39 \\
\hline 2002 & 6.47 & 6.93 & 15.33 & 20.80 & 28.39 \\
\hline 2003 & 8.13 & 6.36 & 10.09 & 21.73 & 28.39 \\
\hline 2004 & 8.00 & 6.23 & 11.23 & 22.90 & 26.08 \\
\hline 2005 & 9.32 & 7.10 & 12.08 & 23.94 & 28.17 \\
\hline 2006 & 11.38 & 11.26 & 16.75 & 25.01 & 33.11 \\
\hline 2007 & 10.77 & 9.63 & 17.28 & 26.14 & 36.06 \\
\hline 2008 & 9.06 & 10.69 & 21.40 & 27.31 & 46.71 \\
\hline 2009 & 10.07 & 11.53 & 21.82 & 28.54 & 46.36 \\
\hline 2010 & 10.06 & 12.66 & 20.00 & 29.83 & 43.37 \\
\hline 2011 & 8.98 & 16.58 & 25.15 & 31.17 & 44.10 \\
\hline 2012 & 10.43 & 15.80 & 27.79 & 32.57 & 41.08 \\
\hline 2013 & 9.91 & 14.33 & 25.76 & 34.04 & 40.57 \\
\hline 2014 & 10.84 & 17.06 & 31.01 & 35.57 & 39.43 \\
\hline
\end{tabular}

Sources:

${ }^{a}$ Prices for grade C live cattle are obtained from the Ministry of Agriculture, Water and Forestry, Directorate of Planning, Statistical Bulletins of 2005 and 2009, respectively, and are further supplemented by data obtained in the report produced by Agra Professional Service (2012) for the Northern communal areas carried out for the Meat Board of Namibia.

${ }^{\mathrm{b}}$ Beef prices for grade A cattle are obtained from the several Microsoft Excel spreadsheet provided by the Meat Board data portal (2014) accessible at www.nammic.com.na and Meat Corporation annual reports. These prices are considered as average price per head of cattle and converted to price per kilogramme. It is noted that auction prices are dominate prices because they yield normal profit in both markets. 